\title{
Reducing Floral Initiation and Return Bloom in Pome Fruit Trees-Applications and Implications
}

D uane W. Greene

AdDITIONAL INDEX WORDS. gibberellins, GA, flower bud formation, flower inhibition, CPPU, thidiazuron, pome fruit

Summary. Regulation of biennial bearing in pome fruit is usually accomplished by chemically removing fruit during the "on" cycle. The advantages and disadvantages of regulating biennial bearing by inhibiting flowering in the "off" cycle were discussed. G ibberellins and the two phenyl urea cytokinin-like compounds, thidiazuron and CPPU have been shown to inhibit flowering in pome fruit. It was concluded that inhibition of flowering with commercially available gibberellins was not a commercially acceptable approach to regulate biennial bearing. The inhibition of flowering was erratic, fruit thinning and increased fruit set could not be predicted, and seed abortion following gibberellin application could predispose fruit to reduced postharvest life because of reduced calcium uptake. R egulation of flowering by inhibiting flower bud formation appeared to be a viable way to regulate cropping on nonbearing tress or trees that were not carrying a crop.

C

ontrol of biennial bearing in pome fruit is one of the most difficult tasks that an orchardist is required to do. U sually the focus of attempts to regulate flowering is to increase flower bud formation. The primary way this is done is through chemical thinning, but other strategies such as rootstock and cultivar selection, or appropriate management techniques are often utilized. Another approach to establish more regular flowering is by inhibiting flower bud formation.

\section{Inhibiting flower bud formation}

A representation of the biennial bearing cycle of pome fruit is illustrated in Fig. 1. U nder good pollinating conditions a tree with a snowball bloom will generally have very heavy fruit set. This will result in no or few resting spurs, so there will be limited flower bud formation for the following year. With reduced or no bloom there will be many resting spurs, thus most spurs will initiate flowers for a snowball bloom the following year.

D epartment of Plant and Soil Sciences, U niversity of M assachusetts, Amherst, M A 01003.

The cost of publishing this paper was defrayed in part by the payment of page charges. U nder postal regulations, this paper therefore must be marked adverti sement solely to indicate this fact. 


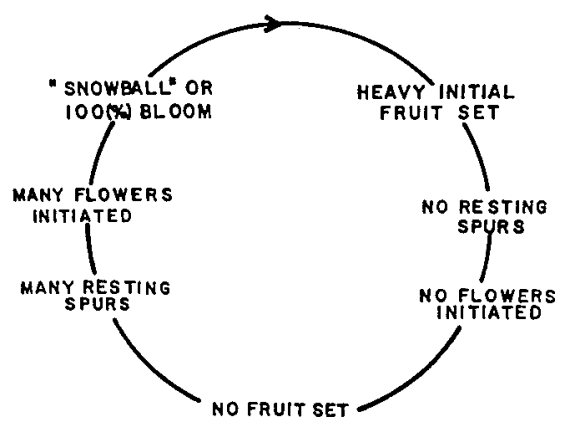

Fig. 1. C ycle of biennial bearing of pome fruit(Williamsand E dgerton, 1981).

Chemical thinning isused to break or modify the biennial bearing cycle, in the year of heavy bloom, by either preventing pollination or ovule fertilization with blossom thinners, or by reducing fruit set with the appropriate application of postbloom thinners(Williams, 1979). An alternative method to break this biennial bearing cycle is to inhibit flowering during the "off" year when there are many resting spurs (L uckwill, 1969). Thegoal with this approach isto apply a hormone spray to inhibit flower bud formation in some of the resting spurs, so that the trees will not have a snowball bloom the following year.

\section{Advantages of reducing biennial bearing by inhibition of flowering}

Chemical thinning is not a precise science, since may factors must interact to producegood thinning results. $M$ any factors have been identified that influence thinner efficacy, but their precise effect, and the way that they interact with other factors has not been established. Weather, and especially tempera ture following application, is a dominant factor that determinestheextent of thinning (Schwallier, 1996). Poor or inadequate thinning may result if the period of fruit susceptibility to chemical thinners and favorable weather following thinner application do not coincide. Some cultivars are extremely biennial, and regulation of flowering by chemical thinners, even if started at bloom, may be insufficient to break the biennial bearing cycle (Forshey, 1986). With thesecultivars, and perhaps with others, inhibition of flowering in the "off" year may bea better way to establish regular flowering.

Increased fruit size may be more easily achieved by inhibiting flowering rather than depending upon chemical thinners. The bloom and postbloom period is a time of intense competition for photosynthate and stored reserves among competing sinksin apples(M alus domestica Borkh.), pears (Pyruscommunis L.) and other pome fruit (Lakso, 1994). Even if chemical thinners reduced crop load to an ideal level after June drop, fruit size at harvest would be affected because of this early fruit-tofruit competition. Cell number is reduced by early fruit competition, and final fruit sizeat harvest is determined by both the number of cells and mean size within a fruit (D enne, 1960). If flower bud formation is inhibited the previous year, there would be fewer flowers and fruit competing during this bloompostbloom period, thus more cell division could occur, and larger fruit may be realized at harvest.

Generally lower bloom density means a larger percent of the flowers present will set fruit (Williams, 1979). This may be an advantage under low light and warm temperature conditions where fewer fruit are in competition for available photosynthate.

Tree growth, especially on young trees, may be improved on trees where flower bud formation has been reduced (U nrath and Whitworth, 1991). The majority of apple trees being planted in the U nited States and elsewhere are propagated on very precocious rootstocks. E arly flowering and fruit set can slow tree growth to the extent that trees are prevented from filling their allotted space, and never reach their full yield potential. Further, heavy set on young trees may cause leader or limb breakage which would result in substantial structural damage to the tree.

\section{Disadvantages of reducing biennial bearing by inhibiting flowering}

There are situations where it is detrimental to reduce numbers of flowers at bloom. The decision to regulate flowering by inhibiting flower bud formation must be made as early as 1 year before flowers actually open. During that 11 or 12 month period many things can happen that may affect the viability of flowers including winter injury, drought stress, and defoliation due to insects or diseases. Poor pollinating weather, poor pollinator activity, or frost at or following bloom may affect fruit set so severely that large numbers of flowers at bloom would be require for adequate fruit set.

$U$ se of chemicalsfor bloom reduction has not been perfected so that growers can select chemicals, timing, and concentrations to give reasonably preciseand predictablereduction in flowering (Greene, 1993). M ore research is required to make flower bud inhibition consistent from year to year.

Theremay beunwanted and undesirablevegetativesideeffects. $\mathrm{H}$ igh rates of some gibberellins may result in production of blind wood (G reene, 1989). Treatments to inhibit flowering may be somewhat incomplete, resulting in the production of small flowers with the potential to produce only small fruit.

\section{Chemicals to inhibit flower bud formation}

The ability of gibberellins to inhibit flowering in pome fruit has been recognized for over a third of a century (M arcelleand Sironval, 1963) and it has been confirmed many times since. The natural cause of biennial bearing in pome fruit appears to reside within the seeds (C han and Cain, 1967). It is believed that the gibberellins produced within the seeds diffuse out and inhibit flowering in the bourse bud (H oad, 1978; Luckwill, 1969). Gibberellins differ in their ability to inhibit flowering in pome fruit ( $M$ arino and $G$ reene, 1981; T romp, 1982 ). While there is not complete agreement in the literature, it appears in general that, $\mathrm{GA}_{4}$ isleast inhibitory, $\mathrm{GA}_{7}$ themost inhibitory, and $\mathrm{GA}_{3}$ and $G \mathrm{~A}_{4+7}$ are intermediate in their ability to inhibitflowering (Tromp, 1982). Looney et al. (1985) provided substantial evidencethat somegibberellinsunder some circumstances may in fact increase flowering. They reported that $\mathrm{GA}_{4}$ and $\mathrm{C}-3$ epi-GA increased flowering in the "off" year on ' $G$ olden $D$ elicious' apple trees.

CPPU [N-(2-chloro-4-pyridyl)$\mathrm{N}$ '-phenylurea] and thidiazuron ( $\mathrm{N}$ phenyl-N '1,2,3-thiadiazol-5-ylurea) are phenylurea compounds with greater cytokinin activity in some systems than that of naturallyoccurring adenine-based cytokinins with a sidechain in the $\mathrm{N}^{6}$ position (Fellman et al., 1987). In addition to reducing return bloom, these compounds have other positive effects that may make them commercially useful on apples. These effectsinclude: fruit thinning, increased fruit size, increased flesh firmness at harvest and following storage, and increased length to diameter (L/D) ratio (Curry and Greene, 
T able1. Effect of timeof application of $150 \mathrm{ppm}\left(\mathrm{mg}^{-\mathrm{L}^{-1}}\right) \mathrm{G} \mathrm{A}_{4+7}$ on fruitset and return bloom of mature'M cl ntosh/M alling7' appletrees. ( $\mathrm{G}$ reene, 1989).

\begin{tabular}{|c|c|c|}
\hline $\begin{array}{l}\text { Time after } \\
\text { full bloom } \\
\text { of } G A_{4+7} \\
\text { application } \\
\text { (d) }\end{array}$ & $\begin{array}{c}\text { Fruit set } \\
\text { in year of } \\
\text { treatment } \\
\text { (fruit/L C SA }) \\
\end{array}$ & $\begin{array}{c}\text { R eturn bloom } \\
\text { in year } \\
\text { after GA } \\
\text { treatment } \\
\text { (blossom clusters/LC SA) }\end{array}$ \\
\hline None & 11.6 & 5.6 \\
\hline-6 & 16.8 & 1.0 \\
\hline 0 & 14.9 & 0.4 \\
\hline 7 & 18.4 & 0.6 \\
\hline 13 & 17.0 & 0.3 \\
\hline 21 & 13.7 & 0.2 \\
\hline 28 & 16.1 & 0.1 \\
\hline 35 & 13.9 & 0.9 \\
\hline 45 & 11.3 & 4.5 \\
\hline 60 & 12.2 & 8.7 \\
\hline Significance & $1^{* * *}$ & $1^{* * *}$ \\
\hline
\end{tabular}

${ }^{\mathrm{z}} \mathrm{N}$ umber per $\mathrm{cm}$ limb cross sectional area; 1.0 fruit or blossom clusters per centimeter of limb cross sectional area $=0.39 /$ inch

${ }^{* * *}$ Significant at $\mathrm{P}=0.001$.

1993; Elfving and Cline, 1993; Greene, 1995, 1996). Compared to gibberellins, verylittleisknown about theflower inhibiting characteristics of these compounds. M ore work is needed to better understand their potential use (so the remainder of this discussion will focus on gibberellins).

\section{Applications and implications for using gibberellins to inhibit flowering}

Types of gibbereluins. Greene (1993) reported on a study where $\mathrm{GA}_{4}$ and $\mathrm{GA}_{4+7}$ wereapplied in each of 4 years to 'Golden Delicious' apple trees in the sameblock at rates and timingsused commercially to reduce fruit russeting. Return bloom was measured the following year. $\mathrm{GA}_{4+7}$ decreased flowering in 3 of the 4 years. GA increased flowering 2 years, had no effect one year, and deceased flowering oneyear. Theconclusion from this series of experiments was that the effects of gibberellins on flowering may be too inconsistent and unpredictable for commercial use.

Times of application. Gibberellins can inhibit flower bud formation over a widerange of timesstarting when applications are made before bloom and extending for several weeksafter bloom. This period of time is essentially the sameasthat where removal of flowersor fruitlets can have a positive effect on flower bud formation. $\mathrm{GA}_{4+7}$ at 150 ppm (mg. $\left.\mathrm{L}^{-1}\right)$ was applied to mature 'M cl ntosh' trees over a 9-week period.
Flowering wasinhibited comparably (less than $20 \%$ of the bloom on nontreated trees) when the gibberellins were applied at pink through 5 weeks after bloom (Table 1). Flowering was inhibited marginally when treatments were applied $45 \mathrm{~d}$ after bloom, whereas there was no effect when treatments were applied $60 \mathrm{~d}$ after bloom. Gibberellins applied at this time can also have the undesirablesideeffect of increasing fruit set with a corresponding reduction in fruit size. Thisdoesnot happen all of the time, but it happensfrequently enough, perhaps $25 \%$ of the time, to be considered a potential problem. Tromp (1982), reported that $500 \mathrm{mg}^{-\mathrm{L}^{-1}}$ of $\mathrm{GA}_{4}$ and $\mathrm{GA}_{4+7}$ inhibited flowering of 1-year-old 'Cox's O range Pippin' trees when applied 9 weeks after bloom whereas the sameconcentration and time of application of $\mathrm{GA}_{4}$ and $\mathrm{GA}_{3}$ had no influence. U nrath and Whitworth (1991) reported that four monthly sprays of $\mathrm{GA}_{4+7}$ beginning 1 month after petal fall eliminated a largeportion of thereturn bloom on young 'D elicious' trees. It appears that the effective period isquitelong for using gibberellins to inhibit flowering on rapidly growing nonbearing trees, and the length of time is influenced by gibberellin type and concentration.

Number of applications. I f flower bud inhibition is caused by gibberellins emanating form seed during early development then one can speculate that the most effective strategy to inhibit flower bud formation may be to mimic this with several application sof a gibberellin over time. H owever, one application made during the first 2 weeks after bloom wasgenerally as effective asmultipleapplications made during the 8 weeks after bloom (Greene, 1989; M arino and Greene, 1981; Tromp, 1982).

Gibberellin concentration. Generally, inhibition of flower bud formation is linear with increasing gibberellin rate (Greene, 1989, 1993).

Crop LoAD. O ne can speculate that less exogenous gibberellin would be required to inhibit flower bud formation as crop load increases, sinceendogenous gibberellins produced by seeds should contribute to inhibiting flower bud formation. Thisisconsistent with the observation that flowering is difficult to inhibit with GA applied to vegetative trees in the "off" year. H owever, other studies indicate that the relationship between intermediate crop loads and GA inhibition of flowering is less clear.

A group of 'E mpire'/ M alling 26 (M .26) treeswereselected and blossom cluster density was adjusted by hand removal of flowersat bloom. All flowers were removed from one group of trees, while some flowers were removed on others trees to achieve four blossom clusters per centimeter (1.56/ inch) of limb cross sectional area, and on some treesno flower adjustment wasmade, to giveafinal bloom density of 13 blossom clusters per centimeter (5.1/ inch) limb crosssectional area. T rees of each bloom density were divided into two groups, those that received two applications of $\mathrm{GA}_{4+7}$ at $50 \mathrm{ppm}\left(\mathrm{mg}^{-\mathrm{L}^{-1}}\right)$ at 7 and $17 \mathrm{~d}$ after full bloom, and those that received no GA. Gibberellins reduced fruit set in theyear of application and return bloom the following year, and blossom removal reduced fruit set but increased return bloom ( $T$ able2). H owever, there wasathinning $\times$ gibberellin interaction. G ibberellin sprays thinned 'E mpire' severely in the year of application, which negated any effects of initial flower density adjustment on bloom the following year. G ibberellins only thin sporadically (perhaps 33\% of my experiments), but this occurs with sufficient frequency that the use of gibberellins to inhibit flowering appears to be inappropriate on cropping apple trees.

\section{Effect of gibberellin sprays on fruit quality}

Gibberellins sprays applied during the postbloom period can reduce seed number and increase the incidence of senescent breakdown ( $G$ reene et al., 1982). Bramlage et al., 1990, 

(BC/L C SA) or leftunadjusted (13 B C /L C SA) at bloom beforeG A application (G reene, 1989).

\begin{tabular}{lccc}
\hline $\begin{array}{l}\text { Bloom density } \\
\text { (BC/LC SA) } \\
\text { when G A } \\
\text { was applied }\end{array}$ & $\begin{array}{c}\mathbf{G A}_{4+7} \\
\text { applications } \\
\text { (no.) }\end{array}$ & $\begin{array}{c}\text { Fruit set } \\
\text { in year } \\
\text { treated } \\
\text { (fruit/L C SA) }\end{array}$ & $\begin{array}{c}\text { Return bloom } \\
\text { in year } \\
\text { after G A } \\
\text { treatments } \\
\text { (BC/L C SA) }\end{array}$ \\
\hline 0 & 0 & 0 & 16.5 \\
4 & 0 & 1.7 & 14.1 \\
13 & 0 & 6.6 & 9.6 \\
0 & 2 & 0 & 8.6 \\
4 & 2 & 0.7 & 9.6 \\
13 & 2 & 1.9 & 8.3 \\
Significance & & $*$ & $* *$ \\
$\quad$ GA & & $* *$ & $*$ \\
Density (D) & & $* *$ & $*$ \\
GA $\times$ D & & & \\
\hline
\end{tabular}

${ }^{\mathrm{z} N}$ umber per centimeter LCSA; 1.0 fruit or BC per centimeter of LCSA $=0.39$ fruit or BC per inch of LCSA.

**** Significant at $\mathrm{P}=0.05$ or 0.01 , respectively.

demonstrated that there is a positive and highly significant linear relationship between seed number in apples and fruit flesh calcium content. Low fruit flesh calcium has been directly associated with reduced postharvest life because of increased instance of senescent breakdown, fruit decay, bitter pit and cork spot. Therefore, if fruit are present on trees that receive a gibberellin spray to reduce flowering, postharvest life of these fruit may be diminished because of low seed number.

\section{Conclusions}

Gibberellinscan effectivelyinhibit flower bud formation on pome fruit trees. H owever, inhibition of flowering on bearing trees to combat biennial bearing is not commercially viable with the current commercial gibberellin formulations because the extent of flower reduction is not predictable, and there are several potentially serious negative side effects which occur inconsistently but at unacceptably high frequency. These negative side effects include increased fruit set, fruit thinning, and reduced postharvest life. H owever, regulation of cropping and inhibition of flowering with gibberellins may be commercially viable on young precocious trees and bearing trees that are in the "off" year.

\section{Literature cited}

Bramlage, W.J., S.A. Weis, and D.W. Greene. 1990. O bservations on the relationships among seed number, fruit calcium, and senescent breakdown in apples. H ortScience 25:351-353.
Chan, B.G. and J.C. Cain. 1967. The effect of seed formation on subsequent flowering in apple. Proc. Amer. Soc. H ort. Sci. 91:63-68.

Curry, E.A. and D.W. Greene. 1993. CPPU influences fruit quality, fruit set, return bloom, and preharvest drop of apples. HortScience 28:115-119.

D enne, M .P. 1960. Thegrowth of applefruitlets, and the effect of early thinning on fruit development. Ann. Bot. 24:397-406.

Elfving, D.C. and R.A. Cline. 1993. Cytokinin and ethephon affect crop load, shoot growth, and nutrient concentration of 'Empire' apple trees. H ortScience 28:1011-1014.

Fellman, C.D., P.E. Read, and M.A. Hosier. 1987. Effects of thidiazuron and CPPU on meristem formation and shoot proliferation. H ortScience 22:1197-1200.

Forshey, C.G. 1986. Chemical fruit thinning of apples. N ew York's Food and Life Sciences Bul. 116.

Greene, D.W. 1989. Gibberellins $A_{4+7}$ influence fruit set, fruit quality, and return bloom of apples. J. Amer. Soc. H ort. Sci. 114:619-625.

Greene, D.W. 1993. Effects of $\mathrm{GA}_{4}$ and $\mathrm{GA}_{7}$ on flower bud formation and russet development on apple. J. H ort. Sci. 68:171-176.

Greene, D.W. 1995. Thidiazuron effects on fruit set, fruit quality, and return bloom. H ortScience 30:1238-1240.

Greene, D.W. 1996. Influence of CPPU on fruit quality and storagepotential of ' $\mathrm{M} \mathrm{Cl}$ ntosh' apples. J. Tree Fruit Prod. 1:87-97.

Greene, D.W., W.J. Lord, and W.J. Bramlage. 1982. Effects of gibberellins $A 4+7$ and 6benzylamino purine on fruit set, fruit characteristics, seed content, and storage quality of ' $\mathrm{M} \mathrm{Cl} \mathrm{n-}$ tosh' apples. H ortScience 17:653-654.
H oad, G.V. 1978. The role of seed derived hormones in the control of flowering in apple. Acta H ort. 80:93-103.

Lakso, A.N . 1994. Apple, p. 3-42. In: B. Schaffer and P.C. Andersen (eds.). H andbook of environmental physiology of fruit crops. vol. 1. Temperate crops. CRC Press, Boca Raton, Fla.

Looney, N .E., R.P. Pharis, and M . N oma. 1985. Promotion of flowering in apple trees with gibberellins $A_{4}$ and $C-3$ epi-gibberellin $A_{4}$. Planta 165:292-294.

L uckwill, L.C. 1969. The control of growth and fruitfulness of apple trees, p. 237-254. In: L.C. Luckwill and C.V. Cutting (eds.). Physiology of tree crops. Academic Press, N ew York.

M arcelle, R. and C. Sironval. 1963. Effect of gibberellin acid on flowering of apple trees. $\mathrm{Na}$ ture 197:405.

M arino, F. and D.W. Greene. 1981. Involvement of gibberellins in the biennial bearing of 'Early M cl ntosh' apples. J. Amer. Soc. H ort. Sci. 106:593-596.

Schwallier, P.G. 1996. Apple thinning guide. Great Lakes Publ. Co., Sparta, M ich.

Tromp, J. 1982. Flower bud formation in apple as affected by various gibberellins. J. $\mathrm{H}$ ort. Sci. 57:277-282.

U nrath, C.R. and J. Whitworth. 1991. Suppression of apple bloom with gibberellin sprays. J. H ort. Sci. 66:155-157.

Williams, M.W. and L.J. Edgerton. 1981. Fruit thinning of apples and pears with chemicals. U SD A Agr. Info. Bul. 289.

Williams, M.W. 1979. Chemical thinning of apples. H ort. Rev. 1:270-300. 